Zeszyty Naukowe Szkoły Głównej Gospodarstwa Wiejskiego

Ekonomika i Organizacja Gospodarki Żywnościowej nr 116, 2016: 5-19

Mariusz Chądrzyński

Katedra Ekonomii i Polityki Gospodarczej

Szkoła Główna Gospodarstwa Wiejskiego w Warszawie

\title{
Poglądy Władysława Grabskiego na postęp i innowacje $w$ rolnictwie
}

\section{Wstęp}

Postęp, wzrost, rozwój oraz innowacje są zagadnieniami ściśle związanymi z gospodarką. Istnieje bardzo dużo teorii, które starają się je wyjaśnić. W wielu aspektach pojęciowych zagadnienia te są ze sobą powiązane. Pojęciowo postęp obejmuje najszersze spektrum zjawisk, zawierając rozwój i wzrost gospodarczy. Tworzenie teorii postępu i wzrostu gospodarczego sięga XVIII wieku, czyli okresu, w którym kształtowały się naukowe podstawy ekonomii jako nauki. W teorii postęp koncentruje się bardziej na zagadnieniach społecznych [Szacki 2006], jednak nie jest on możliwy bez wzrostu i rozwoju gospodarczego. Dopiero Joseph Alois Schumpeter, jako jeden z pierwszych ekonomistów, wprowadził rozróżnienie między wzrostem a rozwojem gospodarczym, określając, że wzrost dotyczy wyłącznie zmian ilościowych, zaś rozwój również jakościowych [Schumpeter 1960]. Uważany jest on także za pierwszego ekonomistę, który wprowadził do literatury pojęcie innowacji. Dodatkowo głosił pogląd, że innowacje są motorem napędowym wzrostu gospodarczego [Glapiński 2004]. Jednak zainteresowanie nauki procesami innowacyjnymi na szerszą skalę miało dopiero miejsce w latach 40-50. XX wieku. Nie oznacza to jednak, że postęp, rozwój i wzrost gospodarczy czy działalność innowacyjna do tego czasu nie istniały. Dopiero w tym okresie zostały one usystematyzowane i stworzono ich naukowe podstawy i teorie. Znaczenie tych pojęć w czasie ewoluowało. Dzięki temu, badając poglądy Władysława Grabskiego na postęp w rolnictwie, można wiele z nich rozpatrywać w kategoriach poglądów na innowacje.

Zarówno Joseph Alois Schumpeter, jak i Władysław Grabski żyli w tym samym okresie na przełomie XIX i XX wieku. Władysław Grabski, jako gruntownie wykształcony mąż stanu i naukowiec, w swych działaniach oraz po- 
glądach był zwolennikiem postępu opartego na wiedzy. Wiele proponowanych i realizowanych przez niego zmian miało charakter innowacyjny, mimo że nie zostały one wprost nazwane innowacjami. Wynikało to z tego, że pojęcie innowacji do literatury Schumpeter wprowadził w 1911 roku [Bielski 2000]. Grabski w swoich poglądach głosił między innymi, że wiedza i postęp nie powinny służyć jedynie przedsiębiorczości, ale również społeczeństwu. W tym znaczeniu jego poglądy odnosiły się do postępu społecznego. Jednocześnie wyrażał on poglądy, że należy stosować nowe rozwiązania w rolnictwie, szczególnie te, które przynoszą wymierne korzyści finansowe. W tym zakresie można uznać, że poglądy Grabskiego odnosiły się do innowacji, choć on sam nazywał je postępem materialnym.

Celem opracowania jest przedstawienie spojrzenia Władysława Grabskiego na postęp $\mathrm{i}$ innowacje $\mathrm{w}$ rolnictwie przez pryzmat jego przemyśleń, głoszonych idei, postaw i podejmowanych działań w tym zakresie.

\section{Metodyka badań}

Zaprezentowane w opracowaniu wyniki są próbą przedstawienia poglądów Władysława Grabskiego na postęp i innowacje w rolnictwie na podstawie badań literaturowych. Opracowanie ma charakter przeglądowy i teoretyczny. Zostało sporządzone na podstawie źródeł pochodzących z literatury dotyczącej poglądów i działalności Władysława Grabskiego. Jako metody badawcze zastosowano metody: intuicyjną, dedukcji, krytycznej analizy literatury, opisową.

\section{Pojęcie innowacji i postępu}

Zagadnienie innowacji jest związane ze zmiana, z nowością, reformą oraz ideą postrzeganą jako nowa. Jako innowacje taktuje się najróżniejsze procesy i zjawiska o charakterze technicznym, organizacyjnym, społecznym czy psychologicznym. Tak zróżnicowane i niesprecyzowane pojmowanie innowacji wynika między innymi z relatywnie krótkiej tradycji badań nad innowacyjnością oraz odmienności i różnorodności ujęć teoretycznych, a także ewolucji paradygmatu innowacji w czasie.

W znaczeniu ogólnym innowacja (łac. innovatis) określana jest jako odnowienie, tworzenie czegoś nowego, wprowadzenie czegoś nowego, rzecz na nowo wprowadzona, nowość, reforma [Tokarski 1980]. W potocznym rozumieniu oznacza coś nowego i innego od dotychczasowych rozwiązań, kojarzy się 
z potrzebną zmianą na lepsze i używane jest jako synonim słowa zmiana [Janasz i Kozioł 2007].

Do lat 40-50. XX wieku, poza nielicznymi wyjątkami, nauka w zasadzie nie wykazywała większego zainteresowania problematyką innowacji. Wynikało to zarówno z przyczyn obiektywnych, jak i subiektywnych, w tym głównie metodycznych, oraz z uwarunkowań historycznych [Fiedor 1979]. We wcześniejszych latach trudno doszukać się i wyodrębnić wyraźnie dwukierunkowych zależności między działalnością wynalazczą a produkcyjną oraz między działalnością naukową a wynalazczą. Historycy nauki i techniki twierdzą, że do połowy XIX wieku technologia wyraźnie wyprzedzała naukę, skutkiem czego nawet jednokierunkowa współzależność była słabo rozwinięta [Fiedor 1979]. Z przyczyn subiektywnych wymienić można nieprzygotowanie przez teorię metod i form analizy, które byłyby właściwe do badań tak dynamicznych procesów jak postęp naukowo-technologiczny oraz procesy innowacyjne. Pomimo tego, że teoria ekonomiczna podejmowała badania o charakterze dynamicznym, jak choćby modele wzrostu, to jednak w badaniach tych przyjmowano niemierzalny stan nauki i techniki, bądź też zakładano, że rozwój tych dziedzin wynika z eksploatacji dotychczasowych trendów [Fiedor 1979]. Można stwierdzić, że zainteresowanie nauki innowacjami w szerszym zakresie rozpoczęło się w latach 40-50. XX wieku, mimo że pojęcie innowacji do literatury ekonomicznej zostało wprowadzone w 1911 roku przez Schumpetera. Wynikało to głównie ze zmiany sposobu myślenia o rozwoju społecznym i gospodarczym. Następowało stopniowe odchodzenie od tradycyjnego podejścia do przedsiębiorstwa jako podmiotu przynoszącego zysk jego właścicielom do podejścia, które wskazywało na podstawową rolę przedsiębiorstwa w generowaniu rozwoju [Bielski 2000]. Na początku problematykę innowacji rozpatrywano tylko w ujęciu makroekonomicznym, podejmując badania dotyczące wpływu postępu technicznego na rozwój gospodarczy. Dopiero w późniejszym czasie pojawiły się badania o charakterze mikroekonomicznym, w których postęp technologiczny potraktowany został jako proces i rozpoczęto badanie jego składowych.

Pojęcia związane $\mathrm{z}$ innowacjami są $\mathrm{w}$ różnorodny sposób przedstawiane przez różnych autorów. Po raz pierwszy pojęcie innowacji do nauk ekonomicznych wprowadził Schumpeter, który określał innowacje bardzo szeroko jako:

1) wprowadzenie nowego towaru lub jego gatunków, z jakimi klienci nie mieli jeszcze do czynienia lub też udoskonalenie już istniejących;

2) wprowadzenie nowej metody produkcji jeszcze praktycznie nieprzyjętej w danej dziedzinie przemysłu;

3) otwarcie nowego rynku, czyli takiego, na którym dany rodzaj krajowego przemysłu uprzednio nie działał i to bez względu, na to, czy rynek ten istniał wcześniej, czy też nie; 
4) zastosowanie nowego sposobu sprzedaży lub zakupów;

5) zdobycie nowego źródła surowców lub półfabrykatów i to niezależnie od tego, czy źródło już istniało, czy też musiało być dopiero stworzone;

6) wprowadzenie nowej organizacji jakiegoś przemysłu, np. stworzenie monopolu bądź jego złamanie [Schumpeter 1960].

Kluczowym słowem w przedstawionej przez niego definicji jest określenie nowy. Schumpeter wiązał innowację z pierwszym zastosowaniem danego rozwiązania, rozumiał je jako tworzenie zmian fundamentalnych lub radykalnych, obejmujących transformację nowej idei lub technologicznego wynalazku w rynkowy produkt lub proces. Nie uznawał za innowacje ich upowszechniania. Wszelkie upowszechnianie innowacji stanowi jego zdaniem, odrębny rodzaj zmian, które określił mianem imitacji. Oznacza to, że innowacja stanowi każdorazowo zmianę niepowtarzalną (jednorazową, nieciagła), zmiany o charakterze imitacyjnym lub inwencyjnym mają zaś ciagły, powtarzalny przebieg. Przypisywał on również duże znaczenie osiągnięciu pozytywnego wyniku ekonomicznego z wprowadzenia innowacji i możliwości jej wykorzystania w praktyce. Schumpeter skupiał się przede wszystkim na innowacjach technicznych i ich znaczeniu dla gospodarki [Niedzielski i Rychlik 2006].

Podobnie jak Schumpeter innowacje szeroko interpretowali także Alvin J. Harman, Dag E. Hagen, Joseph Parker oraz Percy R. Whitfield. Ostatni z nich innowacje określał jako ciąg skomplikowanych działań polegających na rozwiązywaniu problemów. W rezultacie powstaje kompleksowa, całkowicie opracowana nowość [Whitfield 1979]. Do reprezentantów wąskiego podejścia do innowacji zaliczyć można Simona Kuznetsa, Christophera Freemana oraz Edwina Mansfielda. Christopher Freeman uznawał za innowacje pierwsze handlowe wprowadzenie nowego produktu, procesu, systemu lub urządzenia [Janasz i Kozioł 2007].

Michael E. Porter definiuje innowacje jako pomyślną ekonomicznie eksploatację nowych pomysłów. Tak pojmowane innowacje są traktowane jako kontinuum zmian techniczno-organizacyjnych, obejmujące z jednej strony proste modyfikacje istniejących produktów, procesów i praktyk mogące być nowe dla firmy ale niekoniecznie dla przemysłu, z drugiej strony fundamentalnie nowe produkty i procesy, które są nowe zarówno dla przemysłu, jak i dla firmy. Według Portera realizacja innowacji obejmuje cały ciąg czynności naukowych, technologicznych, organizacyjnych, finansowych i handlowych [Porter 1990].

Jeszcze inny jest sposób postrzegania innowacji przez Philipa Kotlera, według którego innowacją jest wszystko postrzegane jako nowość [Kotler 1994]. Pogląd ten rozwinął Peter F. Drucker, twierdząc, że innowacją jest świadoma i korzystna zmiana, jaka wynika z potrzeb lub systematycznej obserwacji otoczenia [Drucker 1992]. W obu przypadkach można zauważyć powrót do genezy 
pojęcia innowacji stwierdzającego, że innowacja może występować w każdym obszarze działalności ludzkiej, o ile prowadzi do powstania czegoś nowego.

Kwestią, która dzieliła badaczy zagadnień związanych z innowacjami, było pytanie, czy za innowacje można uznać tylko pierwsze zastosowanie wynalazku, czy innowacje można również traktować jako powielanie innowacji zastosowanych w innych jednostkach, czyli imitacje. Połączenie tych kwestii widać w poglądach Roberta E. Johnstona, który twierdził, że określenie innowacja stosuje się nie tylko do pierwszego zastosowania wyrobu czy też metody wytwarzania, ale także do kolejnych, gdy zmiany te są stosowane przez inne przedsiębiorstwa, sektory przemysłu, a nawet kraje [Janasz i Kozioł 2007].

Pierwsza teoria innowacji sformułowana przez Schumpetera dotyczyła funkcjonowania gospodarki kapitalistycznej z początku XX wieku. W gospodarce tej główną rolę odgrywały ziemia, produkcja i kapitał. Takie czynniki jak wiedza i informacja, które są ważne obecnie, były na drugim planie. Pod koniec XX wieku zmienił się system techniczno-ekonomiczny całej gospodarki w wyniku wprowadzenia radykalnych zmian istniejących produktów i procesów, nastąpiła również zmiana paradygmatu techniczno-ekonomicznego. Spowodowało to zwiększenie znaczenia wiedzy i informacji w gospodarce. Zmiany te przyczyniły się do większego zainteresowania się problematyką innowacyjną, co spowodowało, że klasyczne ujęcie schumpeterowskie funkcjonujące do II wojny światowej zaczęło ustępować miejsca nowym koncepcjom. Zmniejszenie znaczenia przemysłu na rzecz usług sprawiło, że zakres przedmiotowy innowacji znacznie się rozszerzył i wyszedł poza strefę techniki [Janasz i Kozioł 2007]. W kolejnych późniejszych definicjach innowacje interpretowano w szerokim bądź wąskim znaczeniu. W wąskim ujęciu jest nią wynalazek mający przydatne zastosowanie, wprowadzony do użytku z właściwym wykorzystaniem, a w szerszym ujęciu cały proces zarządzania obejmujący różnorodne czynności, prowadzące do tworzenia i wprowadzania nowych wartości w produktach lub nowych połączeń środków i zasobów, które są nowością dla tworzącej lub wprowadzającej jednostki [Niedzielski i Rychlik 2006].

W Polsce badacze zagadnieniami innowacji interesowali się od końca lat 60. XX wieku. Zainteresowania te koncentrowały się głównie na aspekcie technicznym. Dopiero transformacja systemowa sprawiła zmiany w sposobie postrzegania innowacji oraz działalności innowacyjnej przedsiębiorstw. Główna zmiana polegała na eksponowaniu ekonomicznego aspektu innowacji, aspekt techniczny miał zaś znaczenie drugoplanowe. Podobne tendencje widoczne były w Ameryce Północnej i Europie Zachodniej już w latach 70. XX wieku [Janasz i Kozioł 2007].

Współcześnie powszechnie uznawane i stosowane określenia związane z innowacjami zawarte są w sporządzonym wspólnie przez OECD i Eurostat (wydanym w 2005 roku) opracowaniu „Podręcznik Oslo. Zasady gromadzenia 
i interpretacji danych dotyczących innowacji”. Pojęcie innowacji zostało w nim określone jako wdrożenie nowego lub znacząco udoskonalonego produktu (wyrobu lub usługi) lub procesu, nowej metody organizacyjnej lub też nowej metody marketingowej w praktyce gospodarczej, organizacji miejsca pracy lub stosunkach z otoczeniem [Podręcznik Oslo 2005]. Definicja ta interpretuje innowacje w szerokim znaczeniu, przy czym dopuszcza się interpretację innowacji w węższym zakresie jako wdrożenie jednego lub kilku typów innowacji. Węższą definicję innowacji w obrębie produktów i procesów w szczególności można odnieść do określenia innowacji technologicznych w obrębie produktów i procesów. Istotnym jest to, że minimalnym wymogiem zaistnienia innowacji jest fakt, żeby produkt, proces, metoda organizacyjna lub marketingowa były nowe lub znacząco udoskonalone dla przedsiębiorstwa. Dotyczy to produktów, procesów czy metod, które dane przedsiębiorstwo opracowało jako pierwsze, oraz tych, które zostały przyswojone od innych podmiotów [Podręcznik Oslo 2005].

Tak skonstruowana definicja innowacji obejmuje pełne spektrum nowości - od nowości na skalę światową, czyli innowacji absolutnych, poprzez nowości w skali rynku, na którym działa przedsiębiorstwo, po nowości tylko z punktu widzenia danego przedsiębiorstwa, przy czym innowacja nie musi być opracowana przez wdrażające ją przedsiębiorstwo. Przedsiębiorstwa mogą również wdrażać innowacje opracowane we współpracy z innymi przedsiębiorstwami czy instytucjami, a także innowacje, których autorami są inne przedsiębiorstwa lub instytucje.

Z innowacjami ściśle związane jest zjawisko postępu, chociaż nie należy całkowicie utożsamiać tych pojęć. Postęp jest w swej istocie zmianą dotychczasowego stanu rzeczy na stan pod pewnymi względami lepszy. Innowacja natomiast obejmuje zjawiska związane z postępem, ale nie tylko postępem technicznym, lecz również organizacyjnym, ekonomicznym i społecznym. Zasadnicza różnica między postępem a innowacją polega na tym, że efekty ekonomiczne procesów innowacyjnych muszą być mierzalne na poziomie mikroekonomicznym, zaś efekty różnego rodzaju postępu mogą być trudne do zmierzenia na tym poziomie. Dopiero na poziomie makroekonomicznym możliwe jest ich określenie. Wynika to głównie $\mathrm{z}$ faktu, że głównym celem postępu jest zmniejszenie społecznych nakładów pracy lub rozszerzenie zakresu zaspokajania potrzeb bądź polepszenie warunków pracy. $\mathrm{W}$ innowacji natomiast podstawowym celem jest pozytywny efekt ekonomiczny, podczas gdy postęp może być neutralny z punktu widzenia rachunku ekonomicznego [Niedzielski i Rychlik 2006] - tabela.

W ogólnym znaczeniu postęp określa się jako progres, stopniowy rozwój, udoskonalenie, ulepszanie, przejście od niższego do wyższego etapu [Sobol 1994]. Pojęcie postępu ma swoje źródło w filozofii. Wiara w postęp była jedną 
Tabela

Różnice między innowacjami a postępem

\begin{tabular}{|l|l|l|}
\hline Czynnik & \multicolumn{1}{|c|}{ Innowacje } & \multicolumn{1}{|c|}{ Postęp } \\
\hline Zakres & obejmuje zjawiska zwiazzane z postępem & $\begin{array}{l}\text { zmiana dotychczasowego stanu na } \\
\text { stan lepszy }\end{array}$ \\
\hline Cel & pozytywny efekt ekonomiczny & $\begin{array}{l}\text { zmniejszenie społecznych nakładów } \\
\text { pracy, szersze zaspokojenie potrzeb, } \\
\text { lepsze warunki pracy; efekt neutralny }\end{array}$ \\
\hline Efekty & $\begin{array}{l}\text { ekonomiczne kwantyfikowalne } \\
\text { na poziomie mikro }\end{array}$ & $\begin{array}{l}\text { trudne do zmierzenia na poziomie } \\
\text { mikro, widoczne na poziomie makro }\end{array}$ \\
\hline
\end{tabular}

Źródło: Opracowanie własne na podstawie Niedzielski i Rychlik [2006].

z podstawowych zasad światopoglądu francuskich encyklopedystów, a także myślicieli oświecenia i XIX-wiecznych pozytywistów.

Idea postępu pojawiła się w okresie oświecenia. Pogląd, że świat zmienia się na lepsze, stawał się coraz powszechniejszy wśród uczonych oraz filozofów. Jednak dopiero Nicolas de Condorcet oraz Anne Robert i Jacques J.Turgot zajęli się w sposób systematyczny badaniem idei postępu, co zaowocowało stworzeniem teorii postępu. Była to teoria społeczna, która bazowała na następujących założeniach [Szacki 2006]:

- rozwój społeczny ma charakter prawidłowy;

- w rozwoju społecznym regularnie następują po sobie określone fazy;

- rozwój wszystkich dziedzin ludzkiej kultury kumuluje się;

- istnieje możliwość prognozowania przemian społecznych.

W ekonomii istotną rolę odgrywa postęp techniczny rozumiany jako proces zmian rozwojowych techniki wyrażający się poprzez wprowadzenie do procesu produkcji nowych lub udoskonalonych maszyn, urządzeń, narzędzi i nowych technologii, a także przez wykorzystanie w doskonalszy sposób istniejących zasobów [Woźniak 2004].

Można wyróżnić postęp techniczny [Woźniak 2004]:

1. Egzogeniczny - występuje gdy wzrost produkcji następuje bez zwiększenia zużycia zasobów w procesie produkcyjnym. Jest rezultatem pojawienia się lepszych sposobów gospodarowania zasobami, które aktualnie są użytkowane. Istotne jest to, że wdrażanie nowych metod nie pociąga za sobą zazwyczaj zbyt dużych kosztów.

2. Endogeniczny wiąże się z użyciem $w$ procesie produkcji nowych zasobów kapitału, a więc z nowymi inwestycjami umożliwiającymi zwiększenie wydajności pracy. Można wyróżnić postęp techniczny endogeniczny:

- ucieleśniony w pracy, który wdrażany jest przez pracowników aktualnie szkolonych przez przedsiębiorstwo; 
- ucieleśniony w kapitale - dotyczy maszyn instalowanych bieżąco w danym roku obrachunkowym, w przeciwieństwie do maszyn już funkcjonujących, za pomocą których nie osiaga się tego rodzaju postępu technicznego; jest wynikiem zwiększenia intensywności kapitałowej dzięki inwestycji, czyli wzrostu ilości kapitału przypadającego na jednego zatrudnionego.

Postęp techniczny indukowany jest natomiast szczególnym przypadkiem postępu technicznego endogenicznego. Ma to związek z tym, że produkcyjność kapitału w początkowym okresie oddania do eksploatacji nowych maszyn i urządzeń produkcyjnych jest mniejsza od potencjalnej, ponieważ na początku pracownikom brakuje doświadczenia $\mathrm{w}$ posługiwaniu się nowymi technologiami. W tym przypadku produkcyjność nowego kapitału wzrasta z następujących powodów [Woźniak 2004]:

- większej produkcyjności nowego kapitału, która ujawnia się już w momencie oddania do eksploatacji nowych maszyn i urządzeń;

- wpływu zdobywanego doświadczenia w użytkowaniu nowego kapitału.

\section{Zagadnienia postępu i innowacji w rolnictwie w poglądach Władysława Grabskiego}

Władysław Grabski był nie tylko znanym politykiem i mężem stanu, ale również ekonomistą i naukowcem. Po odsunięciu się od polityki, po zamachu majowym, poświęcił się pracy naukowej w Szkole Głównej Gospodarstwa Wiejskiego w Warszawie. Jest autorem około 150 prac poruszających zagadnienia ekonomii, bankowości, nauk politycznych, agronomii społecznej oraz historii i socjologii wsi [Uchwała... 2003]. W swoich pracach odnosił się również do zagadnień postępu w rolnictwie. W wykładach z socjologii i agronomii społecznej Władysław Grabski głosił ideę, że bez postępu kulturalnego i moralnego wsi jej postęp materialny jest niemożliwy [Przychodzeń 1989]. Swoje poglądy na postęp w rolnictwie przedstawił między innymi w przedmowie do wydanej w 1934 roku książki Wiktora Bronikowskiego „Drogi postępu chłopa polskiego”, a także w opracowaniu własnego autorstwa „Reforma agronomji społecznej” wydanym w 1928 roku. Jednak najpełniej przedstawił je w wydanej w 1930 roku publikacji „Zagadnienie postępu rolniczego wobec kryzysu”.

Władysław Grabski twierdził, że kryzys rolniczy w Polsce w ówczesnych czasach przybrał tak zdecydowany charakter, że wywołał najbardziej poważne troski o zasadniczy kierunek nastawienia produkcji rolniczej na linię rozwoju kładącego nacisk na postęp i czerpiącego z wiedzy [Grabski 1930].

Szczególnie skoncentrował się na następujących obszarach: 
- stosowanie nawozów sztucznych;

- stosowanie ulepszonych maszyn;

- melioracje gruntów;

- praca nad oświatą rolniczą.

Grabski uważał, że postęp rolniczy może być skutecznym dzięki upowszechnianiu wiedzy. Twierdził, że do kierowniczej roli w sprawie rozpowszechniania stosowania nawozów sztucznych powołane są stacje doświadczalne oraz sieć pól doświadczalnych i pokazowych. Na organizacje te trzeba kłaść największy nacisk, szczególnie w czasie, gdy niskie ceny zboża są znakiem ostrzegawczym przed bezkrytyczną wiarą w opłacalność każdego nakładu pieniężnego, byleby miał on znamiona postępu. Władysław Grabski twierdził, że opłacalność musi wytworzyć krytyczny umysł samego rolnika i umysł ten należy w nim ukształtować, chcąc, aby postęp nie szedł w jednym roku bezkrytycznie naprzód, a w drugim nie cofał się gwałtownie [Grabski 1930].

W opracowaniu swoim podawał również dane dotyczące spadku drugiego wskaźnika postępu rolniczego, jakim było stosowanie ulepszonych maszyn.

Dużą rolę przypisywał nowoczesnemu na ówczesne czasy przeprowadzaniu prac melioracyjnych, a szczególnie drenowaniu, które to obniża koszty produkcji, czyniąc uprawę łatwiejszą. Jest więc czynnikiem, który właśnie w dobie kryzysu cen nie przestaje się opłacać. Można stwierdzić, że postępowe działania w zakresie melioracji gruntów przynoszą długofalowe korzyści dla rolnictwa [Grabski 1930].

Grabski szczególną rolę przykładał do krzewienia wiedzy i oświaty rolniczej. W swoim opracowaniu stwierdził, że w ostatnich latach praca nad oświata rolniczą szerokich mas ludności została bardzo rozwinięta, zarówno w zakresie oświaty szkolnej, jak i pozaszkolnej wśród dorosłych oraz młodzieży. Oświata ta nastawiona była na wiarę w postęp, w jego skuteczność i w to, że w postępie rolniczym leży najlepszy sposób rozwiązania wszystkich trudności życia wewnętrznego, dotyczących szczególnie włościan posiadających mało gruntów. To właśnie melioracje bez powiększania areału mogą podnieść produktywność. Grabski twierdził, że melioracje rolne i postępowa gospodarka mogą pomóc wszystkim i wydają się one najlepszym i najpewniejszym środkiem, aby małorolnych włościan wydobyć z ubóstwa [Grabski 1930].

Władysław Grabski twierdził, że załamanie się wiary w opłacalność postępu $\mathrm{w}$ rolnictwie równałoby się dla Polski z załamaniem się wiary w jej przyszłość jako narodu. Pozytywny jest jednak fakt, że wiary w jego opłacalność czynniki tego świadome nie tracą [Grabski 1930].

W opracowaniu swoim stwierdzał, że nastąpiło cofnięcie się w stosowaniu nawozów sztucznych nie tylko w Polsce, ale i w innych krajach. Skutek tego będzie taki, że produkcja w najbliższych latach będzie miała tendencję zniżkową, 
ceny zaś tendencję zwyżkową. Grabski apelował, żeby rolnicy nie wycofywali się z drogi postępu w wyniku spadku opłacalności w jednym roku czy dwóch latach [Grabski 1930].

Władysław Grabski stawiał pytanie o to, co robić wobec kryzysu rolniczego, gdy wszystkie środki pomocy doraźnej zawodzą, a rolnicy odwracają się od postępu rolniczego. Jednocześnie odpowiadał na to pytanie w sposób jednoznaczny, że należy trwać na posterunku, oszczędzać i pogłębiać wiedzę, szczególnie tą, która leży u źródeł postępu, ale która jest czymś znacznie głębszym od pospolitych haseł i formuł, jakie postęp w każdej dziedzinie stosuje. Przy czym stwierdza on, że wiedza ta w zakresie ekonomicznym ma wskazać rolnikowi, że nie należy w kalkulacjach stosowania nawozów sztucznych, melioracji czy ulepszonych maszyn korzystać z cen z jednego roku lub dwóch lat, ale z całego ich dłuższego szeregu. Wiedza ta powinna uzmysłowić, że gdy w tym szeregu lat ceny produktów zwierzęcych są wyższe od cen produktów roślinnych, to należy coraz więcej produktów roślinnych używać jako surowca dla produktów zwierzęcych i do tego należy dostosować płodozmiany oraz zaopatrzenie gospodarstwa [Grabski 1930].

Grabski wyrażał pogląd, że w czasie pomyślności gospodarczej i ożywienia koniunktury postęp wymaga szybkich namacalnych wyników. Następuje wtedy rozpowszechnianie gotowych formuł, stosowanie tego, co najnowsze, co wydaje się najdoskonalsze, nie zwracając uwagi na koszty, nie pytając o warunki najlepszego wykorzystania środków i dostosowania ich do spodziewanych skutków. Taki postęp korzysta z nagromadzonej uprzednio wiedzy i rozszerza ją, ale nie pogłębia jej. W okresie kryzysu przychodzi zaś moment na głębszą rozwagę, na wniknięcie w podstawowe niedomagania samych procesów wytwórczych, na szukanie nowych dróg i na pogłębianie wiedzy. Przy czym dla postępu kładącego nacisk na wiedzę i wynalazek nie ma cofania się, a jest przeciwnie - powstaje nowy impuls twórczy, gdy przed postępem stają nowe wymagania [Grabski 1930].

Władysław Grabski stwierdzał, że podniesienie wydajności rolnictwa może dokonać wielkich postępów bez nadprodukcji i bez kryzysów, pod warunkiem, że będzie ono skutkiem obniżenia się kosztów produkcji, a nie rozszerzenia się stosowania kapitału w rolnictwie bez doprowadzenia do tego obniżenia. Uważał on, że dotychczasowe nastawienie wiedzy zmierzało w kierunku wykazania sposobów, jakimi można jak najwięcej, a nie jak najtaniej produkować. Bez uwzględnienia tego ostatniego czynnika wzrost konsumpcji nie może być trwały i musi ulegać wpływom prowadzącym do kryzysu [Grabski 1930].

Grabski podkreślał duże znaczenie wiedzy we wprowadzaniu postępu. Według niego to wiedza ma najwięcej do powiedzenia, aby wskazać najlepsze drogi do postępu. Musi ona znaleźć środki, które pozwoliłyby na osiagnnięcie najlep- 
szych wyników, choćby nie najważniejszych, ale takich, które, będąc wysokimi, będą jednocześnie najmniej kosztowne. Relacja między środkami a wynikami według Grabskiego daje się poprawić albo osiagganiem większej masy produktów, albo wyższej ich jakości [Grabski 1930].

Władysław Grabski w swoich poglądach podkreślał, że wprowadzanie postępowych zmian, oprócz motywu ekonomicznego, powinno bazować na korzystaniu z wiedzy i przekonaniu o słuszności wprowadzania postępu. Stwierdzał, że kapitalizm w zetknięciu z rolnictwem działa schematycznie. Producenci nawozów dają rolnikom gotowe recepty i produkty, ale wielu rolników zaczyna stosować nawozy bez znajomości rzeczy i bez należytego skutku. Tacy rolnicy przy spadku cen odwracają się od dalszego stosowania nawozów. Ci, którzy rozpoczęli stosowanie nawozów nie pod wpływem, jak to określał kapitalizmu, ale pod wpływem głębokiego zrozumienia potrzeb własnej gleby i roślin na nich uprawianych, zapewne pozostaną wierni swoim spostrzeżeniom o potrzebie zasilania gleby nawozami sztucznymi i jedynie ograniczą lub zmodyfikują stosowane dawki. Podobnie sytuacja wygląda w przypadku melioracji i stosowania ulepszonych maszyn [Grabski 1930].

Władysław Grabski zagadnienia rozwoju wiedzy i postępu traktował w szerokim zakresie. Wyrażał pogląd, że wiedza i postęp nie powinny być bezkrytycznymi sługami ducha przedsiębiorczości kapitalizmu. Powinny one być duchowymi pomocnikami ludzkości, społeczeństwa i narodów tylko wtedy, gdy są traktowane na właściwym podłożu krytycyzmu naukowego, który wskazuje, że rolnictwo nie jest tym samym, co przemysł. Główną różnicą jest to, że w rolnictwie działają wytwórczo siły przyrody [Grabski 1930].

Grabski twierdził, że wiedza w stosunku do rolnictwa wymaga szerokiej skali doświadczalnej i ciągłej styczności z życiem rolników. W Polsce ten kontakt wiedzy z życiem wymaga mocniejszego utrwalenia. Grabski uważał, że odruch, jaki wywołał kryzys, a który dał wyraz jak gdyby częściowego zwątpienia w wartość samego postępu, powinien być uznany za odruch chwilowy, o ile przyczyni się do pogłębienia kierunku wiedzy rolniczej i jeszcze większego zespolenia jej z życiem, czyli praktyką. Ubolewał on nad relacjami nauki z praktyką, twierdząc, że w ówczesnym stanie rzeczy sprawa stosunku nauki do życia postawiona jest zasadniczo błędnie i domaga się rozwiązania. Zauważał, że odrębnymi drogami poruszają się ośrodki wiedzy rolniczej, a dotychczasowy stosunek między poszczególnymi ośrodkami nauki i życia nie jest zupełnie właściwym rozwiązaniem tej sprawy. Stosunki te są tylko funkcjonalne, a powinny być organiczne. Upatrywał w tym bariery w rozszerzaniu postępu w rolnictwie [Grabski 1928, 1930].

Jako przykład podawał, że w okresie kiedy rozpoczął się w Polsce ruch w kierunku zakładania stacji doświadczalnych, największy nacisk położony był 
na bliski ich kontakt z życiem. Z czasem kontakt ten zmniejszał się i w większym stopniu przyjęto kierunek zmierzający do wyodrębniania dziedzin nauki od życia niż do ich zbliżania i konsolidacji. W innych krajach z kolei, jak choćby w Niemczech, następowało zbliżenie tych dziedzin. Grabski ubolewał nad tym, iż zaniedbanie to skutkowało tym, że zamiast rozwijać własne, dobre wzorce korzystaliśmy z innych [Grabski 1928, 1930].

W kontekście wprowadzania postępu rolniczego Władysław Grabski wskazywał na konieczność wysunięcia na należne miejsce nauk ekonomiczno-rolniczych. Środkami prowadzenia polityki ekonomicznej w rolnictwie są zarządzenia ekonomiczne w dziedzinie polityki kredytowej, celnej, transportowej, organizacji obrotu zbożem itp. Do planowania tych środków potrzebni są ludzie wykształceni ekonomicznie. Do stosowania ich potrzebni są ludzie nie tylko odpowiednio wykształceni, ale i kompetentni, przy czym to wykształcenie i kompetentność nie są dostateczne, jeśli są zaledwie ogólno-ekonomiczne. Powinny mieć one charakter ekonomiczno-rolniczy. $\mathrm{Z}$ tego powodu Grabski postulował, żeby polityka ekonomiczna rolnicza była przedmiotem osobnych studiów i osobnych specjalizacji naukowych [Grabski 1930].

Władysław Grabski uważał, że rozwój wiedzy ekonomiczno-rolniczej jest koniecznością. Wymaga on liczniejszych katedr ekonomicznych, liczniejszych stanowisk dla sił pomocniczych i dla specjalistów, większej możliwości specjalizacji ekonomicznej, a także stworzenia przynajmniej jednego osobnego wydziału ekonomiczno-rolniczego, który obejmowałby przygotowanie specjalizacji w dziedzinie organizacji gospodarstw, polityki agrarnej, agronomii społecznej, spółdzielczości i polityki rolniczej ekonomicznej. Rozwój wiedzy ekonomiczno-rolniczej argumentował tym, że wiele strat poniosło rolnictwo skutkiem zbytniego dyletantyzmu tych, którzy jego interesy bądź nieumiejętnie stawiali, bądź nieskutecznie ich bronili [Grabski 1930].

W kontekście pierwotnego znaczenia innowacji, które obejmowało wszelkie nowości i reformy, należy podkreślić, że Władysław Grabski nie tylko wyrażał swoje poglądy na ten temat, ale również podejmował działania, które w wielu obszarach można uznać za innowacyjne i postępowe. Zaliczyć do nich można:

1. Przeprowadzenie reformy walutowej i skarbowej.

2. Rozbudowanie systemu banków państwowych i utworzenie potężnego Banku Gospodarstwa Krajowego, który powstał w maju 1924 roku z połączenia trzech państwowych zakładów kredytowych dawnej Galicji. Nadanie nowych podstaw prawnych Pocztowej Kasie Oszczędnościowej i Państwowemu Bankowi Rolnemu.

3. Zapoczątkowanie zmian w strukturze polskiego eksportu i produkcji przemysłowej.

4. Utworzenie zasiłków dla bezrobotnych. 
5. Aktywne uczestnictwo w staraniach o budowę portu gdyńskiego.

6. Wprowadzenie szkół dwujęzycznych, tzw. utrakwistycznych, umożliwiających rozwój kultury mniejszościom narodowym.

7. Przygotowanie projektu reformy rolnej uchwalonej w grudniu 1925 roku, realizowanej aż do wybuchu II wojny światowej. Podstawą jej miała być parcelacja dobrowolna, a dopiero gdyby w ciagu roku rozmiary jej nie osiągnęły 200 tys. ha, rząd miał prawo przystapić do przymusowego wykupu folwarków celem osiagnnięcia tej granicy [Przychodzeń 2004].

\section{Podsumowanie}

Pojęcie innowacji zmieniało swoje znaczenie w czasie - od ogólnego i szerokiego poprzez zawężenie jego pojmowania do na powrót szerokiego zakresu, jaki obejmuje.

Władysław Grabski w czasie swojego życia i działalności zarówno w obszarze polityki, jak i nauki odnosił się do idei postępu i innowacji w sposób pozytywny, ale krytyczny. Przy czym w ówczesnym czasie powszechniejsze było określenie postęp. Pojęcie innowacji, choć już wprowadzone do literatury przez Schumpetera w 1911 roku nie było tak rozpowszechnione. Wiele działań i poglądów Grabskiego odnoszących się do postępu można jednak utożsamiać z odnoszeniem się do innowacji. Władysław Grabski wyprzedzał zmiany w podejściu do pojmowania innowacji. W swoich poglądach podkreślał społeczny charakter ekonomii. Dopiero w latach 40-50. XX wieku w wyniku zmian sposobu myślenia o rozwoju społecznym i gospodarczym dotyczącego odchodzenia od tradycyjnego podejścia do przedsiębiorstwa jako przedmiotu przynoszącego zysk właścicielowi do podejścia wskazującego na podstawową rolę przedsiębiorstwa w generowaniu rozwoju nastąpiło szersze zainteresowanie nauki innowacjami.

Władysław Grabski swoje poglądy na temat postępu w rolnictwie, co jednocześnie można uznać w ówczesnym czasie za innowacje w rolnictwie, utożsamiał ze zrównoważonym stosowaniem, nowoczesnych na tamte czasy, nawozów sztucznych, ulepszonych maszyn, melioracji gruntów oraz kładł szczególny nacisk na szerzenie oświaty w rolnictwie. Nakazywał krytyczny stosunek do postępu. Przestrzegał przed bezkrytycznym dążeniem do postępu, a zarazem wdrażaniem innowacji w krótkim czasie przy oczekiwaniu szybkich efektów. Zalecał, aby postęp i innowacje stosować ze zrozumieniem popartym świadomością wynikającą z wiedzy. 
W kontekście przedstawionych poglądów Władysława Grabskiego na postęp, a zarazem innowacje w rolnictwie, można stwierdzić, że był on zwolennikiem wprowadzania postępu w sposób świadomy i krytyczny.

Dostrzegał istniejący w ówczesnych czasach zbyt duży dystans między wiedzą i nauką a (jak to określał) życiem, czyli praktycznym działaniem. Rozdźwięk ten jest dostrzegalny również $\mathrm{w}$ obecnych czasach i podobnie jak w czasach współczesnych Grabskiemu podejmowane są działania mające na celu zmniejszenie dystansu, jaki dzieli naukę z praktyką, których skuteczność pozostaje kwestią dyskusyjną.

Władysław Grabski głosił ideę, że bez postępu kulturalnego i moralnego na wsi jej postęp materialny jest niemożliwy. Jednym z głównych celów jego działalności było uczynienie z chłopów pełnoprawnych obywateli kraju i zapewnienie im awansu na wyższy poziom materialny i kulturalny.

\section{Literatura}

BIELSKI I., 2000: Przebieg i uwarunkowania procesów innowacyjnych, Oficyna Wydawnicza Ośrodka Postępu Organizacyjnego Sp. z o. o., Bydgoszcz.

BRONIKOWSKI W., 1934: Drogi postęu chtopa polskiego, Seria Prac Społeczno-Gospodarczych nr 41, nakładem Państwowego Instytutu Naukowego Gospodarstwa Wiejskiego w Puławach, skład główny Księgarnia Rolnicza T.O.R., Warszawa.

DRUCKER P.F., 1992: Innowacje i przedsiębiorczość. Praktyka i zasady, PWE, Warszawa.

FIEDOR B., 1979: Teoria innowacji, PWN, Warszawa.

GLAPIŃSKI A., 2004: Kapitalizm, demokracja i kryzys państwa podatków, Szkoła Główna Handlowa w Warszawie, Warszawa.

GRABSKI W., 1928: Reforma agronomji społecznej, nakład własny, Warszawa.

GRABSKI W., 1930: Zagadnienie postępu rolniczego wobec kryzysu, Excionk. Pom. Druk. Roln. S.A. Toruń, Warszawa.

JANASZ W., KOZIOŁ K., 2007: Determinanty działalności innowacyjnej przedsiębiorstw, PWE, Warszawa.

KOTLER P., 1994: Marketing. Analizowanie, planowanie, wdrażanie i kontrola, Gebethner \& Ska, Warszawa.

NIEDZIELSKI P., RYCHLIK K., 2006: Innowacje i kreatywność, Wydawnictwo Uniwersytetu Szczecińskiego, Szczecin.

Podręcznik Oslo. Zasady gromadzenia i interpretacji danych dotyczacych innowacji, wydanie trzecie, OECD\&EUROSTAT, Paryż 2005.

PORTER M.E., 1990: The Competitive Advantage of Nations, The Macmillan Press, London.

PRZYCHODZEŃ Z.J., 1989: Wokół postaci Władysława Grabskiego: materiały z sesji naukowej poświęconej życiu i działalności prof. Władysława Grabskiego. Warszawa, 1 marca 1988. Wydawnictwo SGGW-AR, Warszawa. 
PRZYCHODZEŃ Z.J., 2004: Władysław Grabski - jego życie, praca społeczna, polityczna naukowa, Roczniki Katedry Nauk Humanistycznych SGGW, Z kart historii wsi i postępu w rolnictwie t. 3, Wydawnictwo SGGW, Warszawa.

SCHUMPETER J.A., 1960: Teoria rozwoju gospodarczego, Wydawnictwo Naukowe PWN, Warszawa.

SOBOL E. (red.), 1994: Mały słownik języka polskiego, Wydawnictwo Naukowe PWN, Warszawa.

SZACKI J., 2006: Historia myśli socjologicznej (wydanie nowe), Wydawnictwo Naukowe PWN, Warszawa.

TOKARSKI J. (red.) 1980: Słownik wyrazów obcych PWN, PWN, Warszawa.

Uchwała nr 19-2002/2003 Senatu Szkoly Głównej Gospodarstwa Wiejskiego w Warszawie z dnia 24 lutego 2003 r., Warszawa.

WHITFIELD P.R., 1979: Innowacje w przemyśle, PWE, Warszawa.

WOŹNIAK M.G., 2004: Wzrost gospodarczy. Podstawy teoretyczne, Wydawnictwo Akademii Ekonomicznej w Krakowie, Kraków.

\title{
Wladyslaw Grabski views on progress and innovation in agriculture
}

\begin{abstract}
The study presents Wladyslaw Grabski's views on progress and innovations in agriculture. He supported their introduction in a conscious and not uncritical way. He believed that the effects of the introduction of progress and innovations in agriculture should be considered in the long term perspective. He found it important to disseminate knowledge and educate people connected to agriculture in order to publicise the effectiveness and benefits coming from innovative actions. He was a supporter of the belief that not only the purely economic but also a general social effects should be considered when introducing progress and innovation in agriculture. He was the forerunner of the comprehensive views on those issues
\end{abstract}

Key words: Wladyslaw Grabski, progress, innovation, agriculture 
